\title{
MENINGKATKAN HASIL BELAJAR SISWA MELALUI PENERAPAN MODEL PEMBELAJARAN PROBLEM BASED LEARNING PADA PEMBELAJARAN PKn DI KELAS VIII E SMP STELLA MATUTINA SALATIGA
}

\author{
Nani Mediatati \\ Nani.mediatati@Staff.uksw.edu \\ Progdi S1 PPKn FKIP - Universitas Kristen Satya Wacana
}

Adi Sukoco

Progdi S1 PPKn

Alumni Progdi S1 PPKn FKIP Universitas Kristen Satya Wacana

\begin{abstract}
ABSTRAK
Penelitian ini bertujuan meningkatkan hasil belajar PKn dalam ranah kognitif, afektif dan psikomotor melalui penerapan model pembelajaran Problem Based Learning (PBL) pada siswa kelas VIII E SMP Stella Matutina Salatiga Semester I Tahun Pelajaran 2015/ 2016. Jenis penelitian adalah penelitian tindakan kelas (PTK) yang terdiri dari dua siklus dengan setiap siklusnya meliputi tahap perencanaan, pelaksanaan tindakan, observasi, dan refleksi. Subjek penelitian yaitu siswa kelas VIII E SMP Stella Matutina Salatiga, yang berjumlah 33 siswa. Teknik pengumpulan data menggunakan observasi, tes, dan non tes. Non tes dengan daftar cek dan skala penilaian digunakan untuk mengumpulkan data hasil belajar ranah afektif dan psikomotorik. Sedangkan tes untuk mengumpulkan data tentang hasil belajar ranah kognitif. Teknik analisis data yang digunakan yaitu teknik deskriptif komparatif dengan membandingkan hasil belajar ranah kognitif pra siklus, siklus 1 dan siklus 2 sampai mencapai indikator keberhasilan penelitian yaitu 100\% siswa tuntas KKM dan hasil belajar ranah afektif dan psikomotorik 100\% siswa mencapai skor antara 18-25 dengan kriteria baik/sangat baik.

Hasil penelitian menunjukkan adanya peningkatan hasil belajar siswa dalam ranah kognitif, afektif dan psikomotor melalui penerapan model pembelajaran Problem Based Learning. Hasil belajar ranah kognitif pada pra siklus ada 21 siswa (70\%) yang tuntas mencapai KKM e" 75, dengan nilai rata-rata yaitu 66. Pada siklus 1 meningkat ada 25 siswa $(83,33 \%)$ yang tuntas dengan nilai rata-rata yaitu 68 , dan pada siklus 2,30 siswa $(100 \%)$ tuntas dengan nilai rata-rata yaitu 75. Hasil belajar ranah afektif pada siklus I ada 6 siswa (20\%) yang nilainya kurang (skor 10-11), 9 siswa (30\%) nilainya cukup (skor 15-16), 13 siswa $(43,33 \%$ ) nilainya baik (skor 18-20), dan 2 orang $(6,67 \%)$ nilainya sangat baik (skor 22-25). Hasil belajar ranah psikomotorik pada siklus 1 ada 4 siswa $(13,33 \%)$ yang nilainya kurang (skor10-11), 11 siswa (36,67\%) nilainya cukup (skor15-16), 12 siswa (40\%) nilainya baik (skor18-20), dan 3 siswa (10\%) nilainya sangat baik (skor 22-25). Pada siklus II hasil belajar ranah afektif meningkat menjadi 20 siswa $(66,67 \%$ ) nilainya baik (skor18-20) dan 10 siswa $(33,33 \%)$ nilainya sangat baik (skor 22-25). Hasil belajar ranah psikomotorik juga meningkat menjadi 22 siswa (73,33\%) nilainya baik (18-20), dan 8 siswa (26,67\%) nilainya sangat baik (skor 22-25). Ini berarti bahwa hasil belajar ranah kognitif, afektif, dan psikomotorik pada akhir siklus $2100 \%$ siswa telah mencapai indikator keberhasilan penelitian.
\end{abstract}

Kata Kunci: Problem Based Learning, Hasil belajar ranah kognitif, ranah afektif, ranah psikomotorik 


\section{PENDAHULUAN}

Pendidikan Kewarganegaraan merupakan mata pelajaran yang memfokuskan pada pembentukan warga negara yang memahami dan mampu melaksanakan hakhak dan kewajibannya untuk menjadi warga negara yang baik, cerdas, trampil dan berkarakter yang diamanatkan oleh Pancasila dan UUD 1945 (PP No.19 tahun 2005 tentang Standar Nasional Pendidikan). Oleh karena itu Pendidikan Kewarganegaraan merupakan salah satu mata pelajaran yang sangat penting dalam membentuk watak dan kepribadian seseorang. Melalui Pendidikan Kewarganegaraan diharapkan dapat ditanamkan jiwa/nilai-nilai Pancasila dan UUD 1945 kepada generasi muda sehingga menjadi warga negara yang baik, bertanggung jawab dan bertakwa kepada Tuhan Yang Maha Esa.

Berdasarkan hakekat dari mata pelajaran Pendidikan Kewarganegaraan tersebut maka dalam pembelajaran Pendidikan Kewarganegaraan guru dituntut tidak hanya mengembangkan kemampuan siswa dalam ranah kognitif (pengetahuan), tetapi juga kemampuan dalam ranah afektif (sikap) dan psikomotorik (ketrampilan). Untuk itu guru perlu menggunakan strategi dan model pembelajaran yang mampu mengembangkan kemampuan siwa dalam tiga ranah tersebut.

Model pembelajaran berbasis masalah merupakan salah satu model pembelajaran yang dianggap efektif untuk mengembangkan kemampuan siswa dalam ranah kognitif, afektif dan psikomotorik sebagaimana dikemukakan oleh Arends (dalam Warsono dan Hariyanto 2012:147) bahwa pembelajaran berbasis masalah merupakan model pembelajaran yang menggunakan masalah dunia nyata sebagai suatu konteks bagi siswa untuk belajar tentang cara berpikir kritis dan ketrampilan pemecahan masalah serta untuk memperoleh pengetahuan dan konsep yang esensial dari materi pelajaran. Pembelajaran berbasis masalah membantu siswa untuk memproses informasi yang sudah jadi dalam benaknya dan menyusun pengetahuan mereka sendiri tentang dunia sosial dan sekitarnya. Melalui pembelajaran berbasis masalah ini siswa sedikit demi sedikit akan berkembang secara utuh, artinya perkembangan siswa tidak hanya terjadi pada ranah kognitif, tetapi juga ranah afektif dan ranah psikomotor melalui penghayatan secara internal akan problema yang dihadapi selama proses pembelajaran.

Namun demikian pada kenyataanya guru Pendidikan Kewarganegaraan masih banyak yang menggunakan metode ceramah dalam pembelajarannya dengan alasan adanya tuntutan untuk menyelesaikan materi pelajaran tepat pada waktunya. Pembelajaran dengan metode ceramah membuat siswa pasif dan tidak mendorong siswa untuk mengembangkan kemampuan berpikir kritis. Kemampuan siswa yang dikembangkan hanya pada ranah kognitif tingkat rendah (hafalan).

Kondisi pembelajaran tersebut juga terjadi di SMP Stella Matutina. Berdasarkan observasi dalam pembelajaran Pendidikan Kewarganegaraan (PKn) di kelas VIIIE guru hanya menggunakan metode ceramah diselingi tanya jawab. Hal tersebut menyebabkan siswa menjadi pasif karena hanya mendengar penjelasan dari guru dan hanya sebagian kecil siswa yang menjawab pertanyaan guru. Evaluasi yang dilakukan juga hanya sebatas pada ranah kognitif. Namun demikian hasil evaluasinyapun tidak memuaskan karena masih ada siswa yang mendapat skor/nilai dibawah $\mathrm{KKM} \geq 75$. Hal tersebut disebabkan karena siswa kurang 
memahami materi pelajaran sehingga tidak dapat mengerjakan soal tes yang menyebabkan hasil belajarnya rendah. Dari hasil postes pada materi "Pancasila sebagai ideologi dan dasar negara" hanya 21 siswa (70 \%) yang mencapai KKM, 9 siswa (30\%) belum mencapai KKM, dan nilai rata-rata kelas yaitu 66 (masih dibawah KKM).

Berdasarkan permasalahan rendahnya hasil belajar siswa dalam ranah kognitif, serta belum dikembangkan dan dievaluasinya ranah afektif dan psikomotor, maka dilakukan perbaikan pembelajaran Pendidikan Kewarganegaraan melalui penelitian tindakan kelas untuk mengatasi permasalahan tersebut dengan menerapkan model pembelajaran Problem Based Learning (PBL). Melalui penerapan model pembelajaran Problem Based Learning (PBL) diharapkan dapat meningkatkan hasil belajar siswa dalam ranah kognitif, afektif, dan psikomotorik.

Berdasarkan latar belakang dan identifikasi masalah maka dirumuskan masalah penelitian: Apakah penerapan model Problem Based Learning (PBL) dapat meningkatkan hasil belajar PKn dalam ranah kognitif, afektif dan psikomotorik pada siswa kelas VIII E semester I tahun pelajaran 2015/2016 di SMP Stella Matutina Salatiga?. Tujuan penelitian ini adalah untuk mendiskripsikan peningkatan hasil belajar PKn dalam ranah kognitif, afektif dan psikomotorik melalui penggunaan model Problem Based Learning (PBL) pada siswa kelas VIII E semester I tahun pelajaran 2015/2016 di SMP Stella Matutina Salatiga.

\section{TINJAUAN PUSTAKA}

\section{Model Problem Based Learning (Pembelajaran Berbasis Masalah)}

Tan dalam Rusman (2011:229) menyatakan bahwa pembelajaran berbasis masalah merupakan inovasi dalam pembe- lajaran karena kemampuan berpikir siswa betul-betul dioptimalisasikan melalui proses kerja kelompok atau tim yang sistematis, sehingga siswa dapat memperdayakan, mengasah, menguji, dan mengembangkan kemampuan berpikirnya secara berkesinambungan. Artinya dalam pembelajaran berbasis masalah siswa dituntut untuk benarbenar berpikir dalam memecahkan pemasalahan yang dilakukan melalui kerja sama dengan kelompok dalam memecahkan permasalahan-permasalahan. Selanjutnya menurut Hemelo Silver dkk, dalam Paul Eggen dan Don Kauchak, (2012:307) pembelajaran berbasis masalah adalah seperangkat model mengajar yang menggunakan masalah sebagai fokus untuk mengembangkan ketrampilan pemecahan masalah, materi, dan pengaturan diri. Tujuan dari pembelajaran berbasis masalah ini antara lain: (1) membantu siswa mengembangkan ketrampilan berpikir dan ketrampilan pemecahan masalah, dengan memberikan dorongan kepada siswa untuk tidak hanya sekedar berpikir sesuai yang bersifat konkret, tetapi lebih dari itu berpikir terhadap ide-ide yang abstrak dan kompleks dengan menggunakan pemecahan masalah (problem solving) oleh siswa sendiri, (2) membantu siswa belajar peranan orang dewasa yang autentik, dengan mendorong kerja sama dalam menyelesaikan tugas, mendorong pengamatan dan dialog dengan orang lain sehingga secara bertahap siswa dapat memahami peran orang yang diamati atau yang diajak dialog, dan (3) membantu siswa menjadi pembelajar yang mandiri dan otonom dengan bimbingan guru yang secara berulang-ulang mendorong dan mengarahkan mereka untuk mengajukan pertanyaan, mencari penyelesaian terhadap masalah nyata oleh mereka sendiri, siswa belajar untuk menyelesaikan tugas-tugas itu secara 
mandiri dalam hidupnya kelak (Trianto, 2009:94). Berdasarkan tujuan tersebut menunjukkan bahwa pembelajaran dengan model Problem Based Learning dapat meningkatkan kemampuan berpikir kritis dari siswa, ketrampilan memecahkan masalah serta sikap kerjasama dalam menyelesaikan tugas.

Dengan demikian kemampuan siswa yang dikembangkan tidak hanya sebatas pada ranah kognitif, tetapi juga ranah afektif dan psikomotor. Adapun langkah-langkah pembelajaran Problem Based Learning (PBL) mencakup kegiatan sebagai berikut: (1) pertama-tama siswa disajikan suatu masalah, (2) siswa mendiskusikan masalah dalam turorial PBL dalam sebuah kelompok kecil. Siswa mengklarifikasi fakta-fakta suatu kasus kemudian mendefiniskian sebuah masalah, membrainstroming gagasangagasannya dengan berpijak pada pengetahuan sebelumnya, mengidentifikasi apa yang dibutuhkan untuk menyelesaikan masalah serta apa yang tidak diketahui, menelaah masalah tersebut, dan mendesain suatu rencana tindakan untuk menggarap masalah, (3) siswa terlibat dalam studi independen untuk menyelesaikan masalah di luar bimbingan guru. Hal ini bisa mencakup: perpustakaan, database, website, masyarakat, dan observasi, (4) siswa kembali pada tutorial PBL, lalu saling sharing informasi, melalui peer teaching atau cooperative learning atas masalah tertentu, (5) siswa menyajikan solusi atas masalah, dan (5) siswa mereview apa yang dipelajari selama proses pengajaran selama ini. Semua yang berpartisipasi dalam proses tersebut terlibat dalam review pribadi, review berpasangan, dan review berdasarkan bimbingan guru, sekaligus melakukan refleksi atas kontribusinya terhadap proses tersebut (Miftahul Huda, 2013: 272). Melalui kegiatan tersebut maka siswa akan terbiasa menghadapi masalah dan merasa tertantang untuk menyelesaikan masalah, tidak hanya terikat dengan pembelajaran dalam kelas, tetapi juga menghadapi masalah yang ada dalam kehidupan sehari-hari; memupuk solidaritas sosial dengan terbiasa berdiskusi dengan teman-teman sekelompok kemudian berdiskusi dengan teman-teman sekelasnya; makin mengakrabkan guru dengan siswa; dan membiasakan siswa dalam menerapkan metode ekperimen karena ada kemungkinan suatu masalah harus diselesaikan siswa melalui eksperimen.

\section{Hasil Belajar}

Menurut Dimyati dan Mudjiono, (2013:3) hasil belajar merupakan hasil dari suatu interaksi tindak belajar dan tindak mengajar. Dari sisi guru, tindak mengajar diakhiri dengan proses evaluasi hasil belajar. Dari sisi siswa, hasil belajar merupakan berakhirnya penggal puncak proses belajar. Hasil belajar adalah kemampuan-kemampuan yang dimiliki siswa setelah ia menerima pengalaman belajarnya. Hasil belajar memiliki beberapa ranah atau kategori dan secara umum merujuk kepada ranah penge-tahuan, sikap, dan ketrampilan. Oleh karena itu hasil belajar tidak hanya berupa penguasaan konsep teori mata pelajaran saja, tetapi juga penguasaan kebiasaan, persepsi, kesenangan, minat-minat, penyesuaian sosial, macammacam ketrampilan, cita-cita, keinginan dan harapan (Rusman, 2012:123).

Berdasarkan revisi taksonomi Bloom dalam Lorin W. Anderson dan David R. Krathwohl (2010:99) mengklasifikasikan hasil belajar ranah kognitif menjadi enam aspek yaitu mengingat (remembering), memahami (understanding), mengaplikasi (applying), menganalisis (analyzing), mengevaluasi (evaluating), mencipta (creating). Ranah afektif terdiri lima aspek yaitu 
penerimaan (receiving), partisipasi (responding), penilaian (valuing), organisasi (organization), pembentukan pola hidup (characterization by a value or value complex). Selanjutnya ranah psikomotorik terdiri tujuh aspek yaitu persepsi (perception), kesiapan (set), gerakan terbimbing (guided response), gerakan yang terbiasa (mechanical response), gerakan yang kompleks (complex response), penyesuaian pola gerakan (adjustment), kreativitas (creativity). Ketiga ranah hasil belajar tersebut sebenarnya tidak berdiri sendiri, tetapi selalu berhubungan satu sama lain bahkan ada dalam kebersamaan. Pengukuran hasil belajar ranah kognitif dapat digunakan tes tertulis bentuk uraian, isian singkat, ataupun pilihan ganda. Sedangkan pengukuran hasil belajar ranah afektif dan psikomotorik dapat digunakan bentuk nontes dengan instrumen antara lain skala sikap (attitude scale), daftar cek (chek list), dan skala penilaian (rating scale) (Elis Ratnawulan dan Rusdiana, 2015:187)

\section{METODE PENELITIAN}

Jenis penelitian adalah penelitian tindakan kelas (PTK). Penelitian ini dilaksanakan di kelas VIIIE SMP Stella Matutina Salatiga pada semester I tahun pelajaran 2015/2016. Desain penelitian tindakan kelas menggunakan model Kurt Lewin (dalam Saur Tampubolon, 2014:26) dimana dalam setiap siklus terdiri dari empat tahap yaitu a) perencanaan Tindakan (Planning), b) Pelaksanaan Tindakan (Acting), c) pengamatan (Observing), dan d) refleksi (Reflecting). Penelitian ini dilakukan dalam 2 siklus dan setiap siklusnya terdiri dari 2 kali tatap muka/pertemuan.

Subjek penelitian adalah siswa kelas VIII E yang berjumlah 30 siswa, laki-laki 13 orang dan perempuan 17 orang. Teknik pengumpulan data menggunakan observasi, tes, dan non tes dengan instrumen penelitian berbentuk lembar penilaian tes (soal pilihan ganda), lembar penilaian non tes (daftar cek dan skala penilaian) serta lembar observasi kegiatan proses belajar mengajar.Teknik analisis data yang digunakan adalah teknik deskriptif komparatif dengan membandingkan data hasil belajar siswa sebelum tindakan (pra siklus), setelah tindakan siklus I dan siklus II sampai mencapai indikator keberhasilan yang ditentukan. Indikator keberhasilan Penelitian Tindakan Kelas (PTK) adalah terjadinya peningkatan hasil belajar PKn ranah kognitif dengan KKM 75,0 yang dicapai oleh $100 \%$ siswa/seluruh siswa, sedangkan hasil belajar ranah afektif dan psikomotorik melalui non tes $100 \%$ siswa mencapai skor rata-rata 18-25 dengan kriteria baik/sangat baik.

\section{HASIL PENELITIAN DAN PEMBAHASAN}

Padakondisi awal (pra siklus) sebelum diterapkan model pembelajaran berbasis masalah (Problem Based Learning/PBL) hasil belajar PKn siswa dalam ranah kognitif rendah. Hal tersebut nampak dari 30 siswa dalam satu kelas hanya 21 siswa $(70 \%)$ yang tuntas dengan nilai $\mathrm{KKM} \geq 75$ sedangkan sebanyak 9 siswa (30\%) belum tuntas dan nilai rata-rata yaitu 66 . Hasil belajar ranah afektif dan psikomotorik tidak dievaluasi karena pembelajaran dengan metode ceramah hanya mengembangkan kemampuan kognitif tingkat rendah (menghafal materi).

Pada siklus 1, diterapkan model pembelajaran berbasis masalah (Problem Based Learning/PBL) dengan materi dan KD ke-1 “Menjelaskan Pancasila sebagai dasar Negara dan ideologi Negara yang berlangsung dua kali pertemuan. Kegiatan perencanaan tindakan meliputi membuat Rencana Pelaksanaan Pembelajaran (RPP), 
menyiapkan permasalahan yang terkait dengan sila-sila Pancasila, menyiapkan sumber belajar buku Pendidikan Kewarganegaraan untuk SMP kelas VIII, menyiapkan lembar observasi siswa dan soal evaluasi pembelajaran siklus I yang sudah diuji validitas dan reliabilitasnya. Pelaksanaan tindakan dalam pembelajaran, siswa dibagi menjadi 6 kelompok dimana tiap kelompok terdiri dari 5 siswa dengan pembagian tiga kelompok membahas permasalahan yang terkait dengan sila 1 yaitu konflik antar umat beragama dan 3 kelompok membahas permasalahan yang terkait dengan sila 2 yaitu pelanggaran hak asasi manusia (kekerasan terhadap anak). Kemudian siswa berdiskusi, mencari informasi dari berbagai sumber dan saling tukar informasi (sharing) bersama teman kelompoknya untuk mencari penyebab, dampak dan solusi untuk memecahkan masalah tersebut. Setelah selesai siswa menyajikan solusi masalah dan memaparkan hasil diskusinya di depan kelas bersama teman sekelompoknya dan terjadi tanya jawab antar siswa. Guru dalam kegiatan pembelajaran bertindak sebagai nara sumber, fasilitator, dan motivator. Selanjutnya siswa mereview apa yang mereka peroleh selama mengikuti proses pembelajaran berlangsung dengan berlandaskan materi pelajaran. Pada akhir pembelajaran diadakan evaluasi/tes untuk mengetahui pemahaman siswa terhadap materi pembelajaran untuk menilai hasil belajar kognitif. Penilaian hasil belajar afektif dan psikomotorik dilakukan pada saat poses pembelajaran melalui pengamatan dengan daftar cek dan skala penilaian.

Pada siklus 1 ini setelah diterapkan model pembelajaran berbasis masalah (Problem Based Learning/PBL) hasil belajar siswa dalam ranah kognitif mengalami peningkatan. Hal tersebut terlihat dari meningkatnya jumlah ketuntasan hasil belajar sebanyak 25 siswa $(83,33 \%)$ yang tuntas, sedangkan 5 siswa $(16,67 \%)$ belum tuntas dan nilai rata-rata yaitu 68. Pada ranah afektif yang diamati/dinilai melalui daftar cek adalah perhatian siswa terhadap permasalahan yang dijelaskan guru, keaktifan dalam diskusi dan presentasi, menghargai pendapat teman, bekerjasama dalam kelompok, dan bertanggungjawab dalam mengerjakan tugas dengan kriteria penilaian setiap indikator $1=$ sangat kurang, $2=$ kurang, $3=$ cukup, 4=baik, 5=sangat baik. Dari 30 siswa ada 6 siswa (20\%) yang nilainya kurang (10-11), 9 siswa (30\%) nilainya cukup (1516), 13 siswa $(43,33 \%)$ nilainya baik (18-20), dan 2 orang $(6,67 \%)$ nilainya sangat baik (22-25). Selanjutnya pada ranah psikomotorik yang diamati/dinilai melalui skala penilaian adalah ketrampilan menganalisis masalah, ketrampilan mengemukakan pendapat, ketrampilan bertanya jawab dan diskusi, ketrampilan menyelesaikan masalah dalam kelompok, ketrampilan menyajikan hasil diskusi kelompok dengan kriteria penilaian setiap indikator $1=$ sangat kurang, 2=kurang, 3=cukup, 4=baik, 5=sangat baik. Dari 30 siswa ada 4 siswa $(13,33 \%)$ yang nilainya kurang (10-11), 11 siswa $(36,67 \%)$ yang nilainya cukup (15-16), 12 siswa (40\%) yang nilainya baik (18-20), dan 3 siswa (10\%) yang nilainya sangat baik (22-25). Walaupun ada peningkatan hasil belajar ranah kognitif namun peningkatan ini belum sesuai dengan indikator keberhasilan $100 \%$ tuntas mencapai KKM $\geq 75$. Sedangkan hasil belajar ranah afektif dan psikomotorik baru 50\% siswa yang mencapai kriteria baik/ sangat baik. Oleh karena itu dilakukan perbaikan tindakan pada siklus 2 berdasarkan refleksi dari siklus 1. Dalam proses pembelajaran masih banyak siswa yang belum aktif dalam diskusi kelompok maupun kelas 
sehingga guru perlu memotivasi siswa untuk aktif dengan mendampingi/mengawasi kerja masing-masing kelompok serta memperjelas konsep permasalahan yang terkait dengan materi dalam diskusi kelas agar siswa betulbetul paham terhadap materi pembelajaran.

Pada siklus 2 diterapkan model pembelajaran berbasis masalah (Problem Based Learning/PBL) dengan materi dan $K D$ yang sama tetapi dengan permasalahan yang terkait dengan sila 3 yaitu tawuran pelajar, sila 4 yaitu politik uang dalam Pilkada, dan sila 5 yaitu Korupsi, kolusi, dan nepotisme (KKN) yang berlangsung dua kali pertemuan. Untuk setiap permasalahan dibahas oleh dua kelompok. Perencanaan dan pelaksanaan tindakan sama dengan siklus 1 tetapi dengan perbaikan tindakan khususnya guru lebih memotivasi siswa untuk aktif dan memperjelas konsep permasalahan yang terkait dengan materi. Pada akhir pembelajaran diadakan evaluasi/tes untuk menilai hasil belajar kognitif. Sedangkan penilaian hasil belajar afektif dan psikomotorik dilakukan pada saat poses pembelajaran melalui pengamatan dengan daftar chek dan skala penilaian. Hasil belajar siswa dalam ranah kognitif pada siklus 2 ini mengalami peningkatan yang sangat baik karena dari 30 siswa $100 \%$ tuntas hasil belajarnya dengan $\mathrm{KKM} \geq 75$. Nilai ratarata kelas yaitu 75 sesuai KKM. Pada ranah afektif dari 30 siswa ada 20 siswa $(66,67 \%)$ yang nilainya baik (18-20), dan 10 siswa $(33,33 \%)$ nilainya sangat baik (22-25). Selanjutnya pada ranah psikomotorik dari 30 siswa ada 22 siswa $(73,33 \%)$ yang nilainya baik (18-20), dan 8 siswa $(26,67 \%)$ yang nilainya sangat baik (22-25). Ini berarti bahwa hasil belajar ranah kognitif, afektif, dan psikomotorik $100 \%$ telah mencapai indikator keberhasilan penelitian. Dalam tabel diagram berikut ini disajikan perbandingan hasil belajar siswa ranah kognitif, afektif dan psikomotor dari Pra Siklus, Siklus 1 dan Siklus 2.

Tabel 1 Hasil Belajar Siswa Siswa Kelas VIII E SMP Stella Matutina Salatiga Ranah Kognitif, Afektif dan Psikomotor dari Pra Siklus, Siklus 1 dan Siklus 2

\begin{tabular}{|c|c|c|c|c|c|c|c|c|}
\hline \multirow[b]{2}{*}{ No } & \multirow{2}{*}{$\begin{array}{c}\text { Ranah Hasil } \\
\text { Belajar }\end{array}$} & \multirow[b]{2}{*}{ Nilai } & \multicolumn{2}{|c|}{ Pra Siklus } & \multicolumn{2}{|c|}{ Siklus 1} & \multicolumn{2}{|c|}{ Siklus 2} \\
\hline & & & $\begin{array}{l}\text { Jumlah } \\
\text { Siswa }\end{array}$ & $\begin{array}{c}\text { Persen } \\
(\%)\end{array}$ & $\begin{array}{c}\text { Jumlah } \\
\text { Siswa }\end{array}$ & $\begin{array}{c}\text { Persen } \\
(\%)\end{array}$ & $\begin{array}{c}\text { Jumlah } \\
\text { Siswa }\end{array}$ & $\begin{array}{c}\text { Persen } \\
(\%)\end{array}$ \\
\hline 1 & \multirow{3}{*}{$\begin{array}{l}\text { Ranah } \\
\text { Kognitif }\end{array}$} & tuntas & 21 & 70 & 25 & 83,33 & 30 & 100 \\
\hline 2 & & $\begin{array}{l}\text { tidak } \\
\text { tuntas }\end{array}$ & 9 & 30 & 5 & 16,67 & & \\
\hline 3 & & $\begin{array}{l}\text { nilai } \\
\text { rata- } \\
\text { rata } \\
\end{array}$ & \multicolumn{2}{|c|}{66} & \multicolumn{2}{|c|}{68} & \multicolumn{2}{|c|}{75} \\
\hline 1 & \multirow{4}{*}{ Ranah Afektif } & $\begin{array}{l}\text { sangat } \\
\text { baik }\end{array}$ & - & - & 2 & 6,67 & 10 & 33,33 \\
\hline 2 & & baik & - & - & 13 & 43,33 & 30 & 66,67 \\
\hline 3 & & cukup & - & - & 9 & 30 & - & - \\
\hline 4 & & kurang & - & - & 6 & 20 & - & - \\
\hline 1 & \multirow{4}{*}{$\begin{array}{c}\text { Ranah } \\
\text { Psikomotorik }\end{array}$} & $\begin{array}{l}\text { sangat } \\
\text { baik }\end{array}$ & - & - & 3 & 10 & 8 & 26.67 \\
\hline 2 & & baik & - & - & 12 & 40 & 22 & 73.33 \\
\hline 3 & & cukup & - & - & 11 & 36,67 & - & - \\
\hline 4 & & kurang & - & & 4 & 13,33 & - & - \\
\hline
\end{tabular}



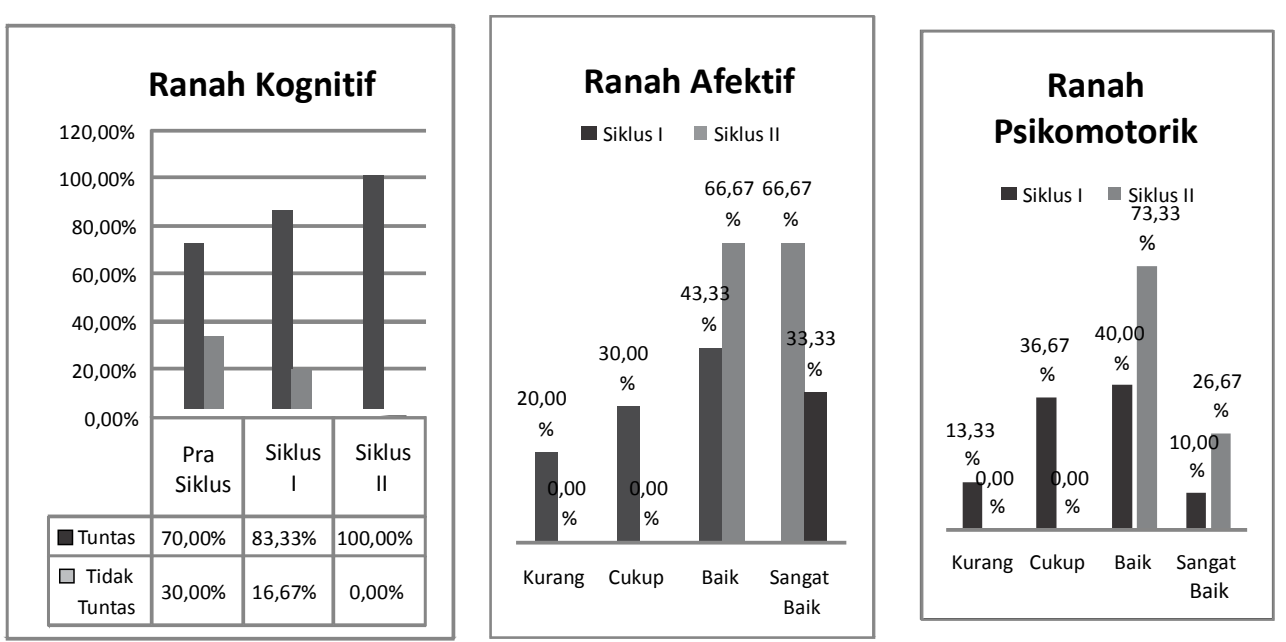

Diagram 1 Hasil Belajar Siswa Kelas VIII E SMP Stella Matutina Salatiga pada Ranah Kognitif, Afektif dan Psikomotorik dari Pra Siklus, Siklus 1 dan Siklus 2

Hasil penelitian ini menunjukkan bahwa penerapan model pembelajaran berbasis masalah (Problem Based Learning/ $P B L)$ dalam pembelajaran PKn dapat meningkatkan hasil belajar ranah kognitif, afektif dan psikomotorik. Karena melalui pemecahan masalah siswa akan lebih mudah memahami materi melalui kerja mandiri maupun bekerjasama dengan teman, memupuk solidaritas sosial dengan terbiasa berdiskusi dengan teman-teman, dapat meningkatkan kemampuan berpikir kritis dan ketrampilan memecahkan masalah yang dihadapi di kelas maupun dalam kehidupan sehari-hari. Hal ini sesuai dengan pendapat Arends (dalam Warsono dan Hariyanto 2012:147) bahwa melalui pembelajaran berbasis masalah siswa sedikit demi sedikit akan berkembang secara utuh, artinya perkembangan siswa tidak hanya terjadi pada ranah kognitif, tetapi juga ranah afektif dan ranah psiokomotor melalui penghayatan secara internal akan problema yang dihadapi selama proses pembelajaran. Hasil penelitian ini sejalan dengan penelitian yang dilakukan oleh Andi Sulis Setiyono (2014) dengan judul Penerapan Model Problem Based Learning (PBL) Untuk Meningkatkan Hasil Belajar PKn Siswa Kelas IV SDN Kedungmulyo Kecamatan Jakenan Pati.
Hasil penelitian menunjukkan adanya peningkatan hasil belajar dalam ranah kognitif, ranah afektif dan ranah psikomotor pada siklus 1 dan siklus 2. Hasil belajar ranah kognitif pada siklus 1 memperoleh ketuntasan klasikal $68 \%$ dan siklus 2 sebesar $88 \%$, hasil belajar ranah afektif pada siklus 1 memperoleh nilai 71,64 dengan kualifikasi baik dan pada siklus 2 memperoleh nilai 83,8 dengan kualifikasi sangat baik, dan hasil belajar ranah psikomotorik siklus 1 memperoleh nilai 69,48 dengan kualifikasi baik pada siklus 2 meningkat menjadi nilai 84,88 dengan kualifikasi sangat baik.

\section{KESIMPULAN}

Berdasarkan hasil penelitian dan pembahasan maka dapat disimpulkan bahwa penerapan model pembelajaran berbasis masalah (Problem Based Learning/PBL) dalam pembelajaran PKn dapat meningkatkan hasil belajar ranah kognitif, afektif dan psikomotorik pada siswa kelas VIII E SMP Stella Matutina Salatiga Semester I Tahun Pelajaran 2015/2016. Hal ini dapat dilihat dari peningkatan hasil belajar siswa pada ranah kognitif, afektif, psikomotor dari pra siklus ke siklus I dan siklus II. 


\section{DAFTAR PUSTAKA}

Anderson, Lorin W dan Krathwohl David R. 2010. Kerangka Landasan Untuk Pembelajaran, Pengajaran dan Asesmen Revisi Taksonomi Pendidikan Bloom. Yogyakarta: Pustaka Pelajar.

Andi Sulis Setiyono. 2014. Penerapan Model Problem Based Learning (PBL) Untuk Meningkatkan Hasil Belajar Pkn Siswa Kelas IV SDN Kedungmulyo Kecamatan Jakenan Pati.

Dimyati dan Mudjiono. 2013. Belajar dan Pembelajaran. Jakarta: Rineka Cipta.

Elis Ratnawulan dan Rusdiana. 2015. Evaluasi Pembelajaran. Bandung: Pustaka Setia.
Miftahul Huda. 2013. Model-model Pengajaran dan Pembelajaran. Yogyakarta: Pustaka Pelajar.

Paul Eggen dan Don Kauchak. 2012. Strategi dan Model Pembelajaran. Jakarta: PT. Indeks.

Rusman. 2011. Model-model Pembelajaran. Jakarta: PT. Rajagrafindo Persada.

Rusman. 2012. Belajar dan Pembelajaran Berbasis Komputer. Bandung: Alfabeta.

Trianto. 2009. Mendesain Model Pembelajaran Inovatif-Progresif. Jakarta: Prenada Media Group.

Warsono dan Hariyanto. 2012. Pembelajaran Aktif. Bandung: Remaja Rosdakarya. 